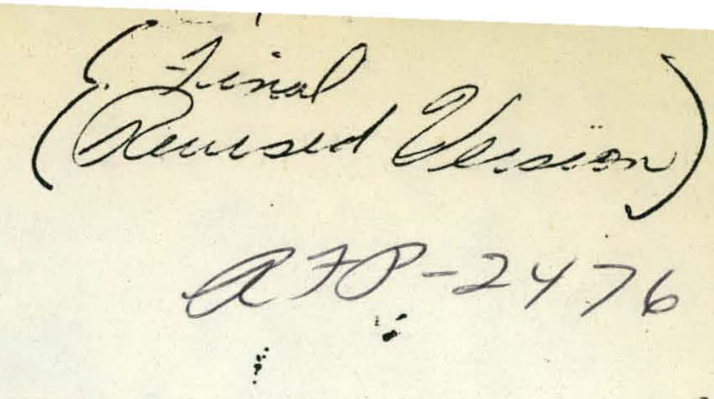

\title{
REVERSE OSMOSIS PILOT PLANT STUDIES FOR THE PURIFICATION AND REUSE \\ OF EFFLUENT FROM A SANITARY \\ WASTE TREATMENT PLANT
}

Carl E. Plock

David E. Hausburg

David R. Horrell
This report was prepared as an account of work sponsored by the United States Government. Neither the United States nor the United States Department of Energy, nor any of their employees, nor any of their contractors, subcontractors, or their employees, makes any warranty, express or implied, or assumes any legal liability or responsibility for the accuracy, completeness or usefulness of any intormation, apparatus, product or process disclosed, or represents that its use would not infringe privately owned rights.

ROCKWELL INTERNATIONAL

Atomics International Division

Rocky Flats Plant

P. O. Box 464

Golden, Colorado 80401 


\section{DISCLAIMER}

This report was prepared as an account of work sponsored by an agency of the United States Government. Neither the United States Government nor any agency Thereof, nor any of their employees, makes any warranty, express or implied, or assumes any legal liability or responsibility for the accuracy, completeness, or usefulness of any information, apparatus, product, or process disclosed, or represents that its use would not infringe privately owned rights. Reference herein to any specific commercial product, process, or service by trade name, trademark, manufacturer, or otherwise does not necessarily constitute or imply its endorsement, recommendation, or favoring by the United States Government or any agency thereof. The views and opinions of authors expressed herein do not necessarily state or reflect those of the United States Government or any agency thereof. 


\section{DISCLAIMER}

Portions of this document may be illegible in electronic image products. Images are produced from the best available original document. 


\section{IBSTRACT}

A description of the Rocky Flats reverse osmosis pilot plant -111 be given, along with some of the data acquired from those operations. A brief description of the equipment recommended for use in the recycling plant is, also included. 


\section{INTRODUCTION}

Rocky Flats is a nuclear weapons facility located in

Colorado, some sixteen air miles northwest of Denver.

The plant is owned by the United States government and is part of the Energy Research and Development Administration's Albuquerque Operations Office. Rockwell International is the operating contractor.

In recent years, the Denver urban sprawl has reached to within only a few miles of the Rocky flats reservation. The City of Broomfield is within three miles of the reservation, and the surface water storage for Broomfield is fed partly by two creeks. which cross the Rocky Flats " reservation. In the 20 plus years that the Rocky Flats plant has been in operation, there have been minor releases of radioactivity and chemical contamination.

In late 1969 the Rocky Flats management first began to look at the possibility of zero discharge of pollutants and complete water recycle. In the years since, four very good and valid reasons why the Rocky Flats plant should reach the goal of zero discharge have come to the fore. Probably, the most important reason was a commitment made by the Rocky Flats management and by the U.S. Atomic Energy Commiesion, the preiteressor of. ERDA, to the 
Governor of the State of Colorado, to the State Health Department, and to the City of Broomfield. That commitment was that the Rocky Flats plant would reach a goal of zero discharge of all aqueous waste. It has always been the policy of the Rocky Flats plant that the effluent leaving the plant would contain the lowest practical limits of contaminants possible for the technology and funding available.

In addition, zero discharge and complete water recycle, will further reduce the remote possibility of any accidental release of contamination, chemical or radiological. It will also permit the plant to accomplish the goal of zero discharge of aqueous pollutants by 1985 which has been set forth in the Water Pollution Control Act of 1972, and we will be conserving a natural resource, water, which in our semi-arid region ma"y become a very precious commodity in the not too distant future.

When the Rocky Flats management began to look at the possibility of complete containment of ail aqueous wastes, the water system at the Rocky Flats plant, as constituted in 1969, is shown in Figure 1.

Rocky Flats purchases, then as now, 10 and one half million gallons of water per month from the Denver Water Board. This water is treated, using standard water treatment methods; to bring the water up to U.S. Public Health standards for drinking. water. The treated water from the water treatment plant was used as procesş water, make-up water for the steam plant, cooling water in the cooling 
WATER USAGE AND DISPOSAL - 1969

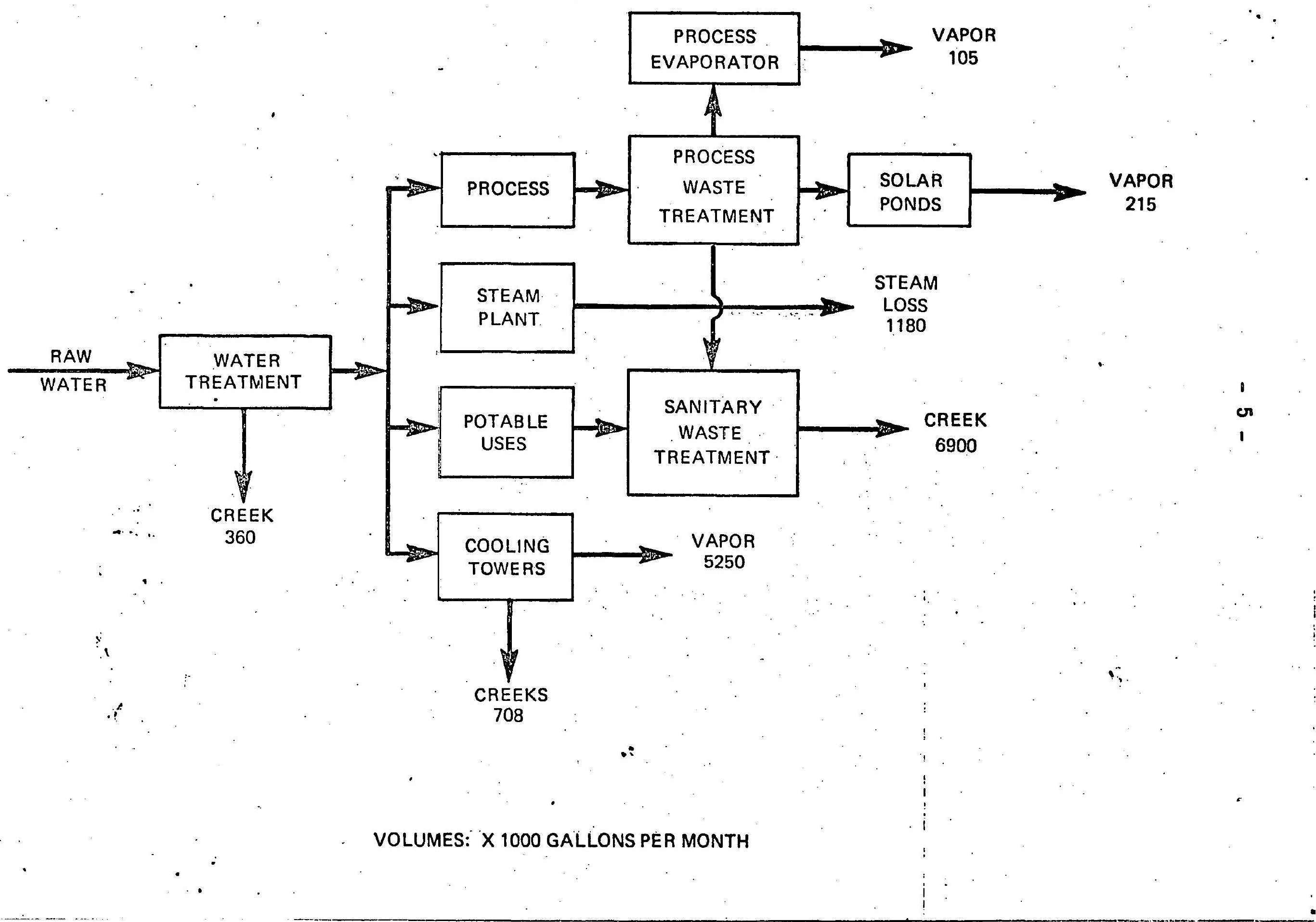


towers and air washers, and for potable uses. The waste water from these operations and uses was discharged into each of the three such drainages that cross the plantsite. The backwash water from the water treatment plant was discharged into Woman Creek, the effluent from the sanitary waste treatment plant which contained some process waste water was released to South Walnut Creek, and the cooling tower blow-down waters were discharged in North Walnut Creek, South Walnut Creek, and Woman Creek.

In the six years since 1969, Rocky Flats has begun the process of "buttoning-up." Figure 2 shows' the present day water usage and disposal. Today, the only discharge ": of waste water to a creek drainage is through the sanitary waste treatment plant. The backwash water from the water treatment plant goes to settling ponds, and the supernate is returned to the raw water system.

The process waste waters which once were fed into the sanitary waste system now go to holding ponds and will be proccssod at a later date. All cooling tower blowdown water-is fed into the sanitary waste system and is discharged along with the other effluent from the sanitary waste treatment plant. 
PRESENT WATER USAGE AND DISPOSAL

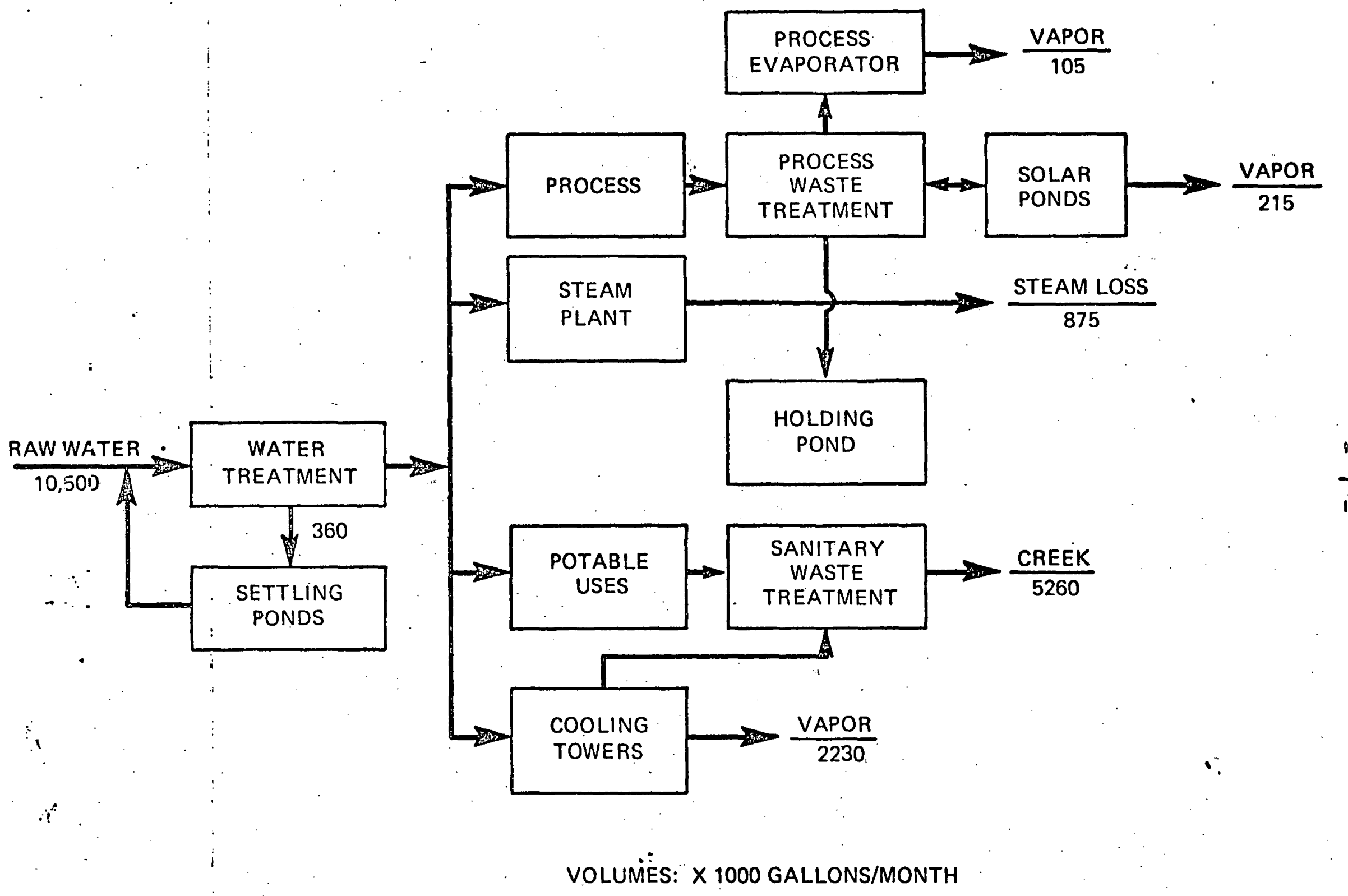


In 1971 it was decided that all process waste waters generated on the plant site, and this included la undry water, would be sent to a new process waste treatment plant. This treatment would include evaporation and spray drying. The distillate would be collected and recycled back into the plant.

There remains only one waste stream to recycle to completely "button-up" the Rocky Flats plant, and have a zero discharge of all aqueous pollutants, the effluent from the sanitary waste treatment plant.

\section{INVOLVEMENT OF RESEARCH AND DEVELOPMENT}

Research and Development first became involved in water recycle approximately five years ago. We focused our attention on the cooling tower blowdown water and on the sanitary waste stream.

When we began to look at the various technology avallable for the purification and recycling of our waste water, we did not consider evaporation. The reasons for this. decision were that we did not have, nor would we have, an evaporator large enough to handle these 1 arge volumes, and also that evaporation is a high energy consumer. 
The technology that we considered are shown in Table $I$.

Ion Exchange - It was eliminated because of the high cost of regeneration and there would still be large volumes of waste solutions that had to be disposed of.

Freeze-Crystallization is one of the newer technology. However, it has a couple of major disadvantages. These are: (1) it consumes large quantities of electrical enersy; (2) it requires a feed water containing 2,000 milligrams per litre or more of total dissolved solids to eperate at maximum efficiency; and (3) the product water from this type of operation would contain approximately 500 milligrams per litre of total dissolved solids: Our feed water will range from 400 to 550 milligrams per litre of total dissolved solids:

Ulirafiltration was eliminated because it does not remove dissolved solids of low molecular weight. It dass an excellent job of improving the clarity of the water. This has been well demonstrated by the pilot pleat on top of Pikes Peak near Colorado Springs.

Elactrodialysis was eliminated because it requires a fezd water containing a minimum concentration of 3,000 milgrams per litre of total dissolved solids to operate 
TABLE I

Technology Considered for Water Purification

1. Ion Exchange

2. Freeze Crystallization

3. U1trafiltration

4. Electrodialys is

5. Reverse osmosis 
properly. If lower concentrations of total dissolved solids in the feed water are used, high resistances are apt to be encountered in some of the cell pairs. This technology is capable of producing a thousand gallons of product water cheaper than any of the technology that were considered.

That left reverse osmosis. These operating costs appeared to be moderate; energy consumption appeared to also be moderate; the pretreatment required was no more than any of the other technology except the freeze-crystallization where the pretreatment is less; and if designed properly, a minimum volume of brine would be produced by a reverse osmosis unit.

\section{REVERSE OSMOSIS PILOT PLANT}

Four years ago, when the laboratory studies were completed, the decision was made to pilot a reverse osmosis unit. It was also decided to locate the pilot operations in a truck trailer because, at that time, we needed that mobility. In the three years that the pilot plant has been operating, we have operated using secondary treated sanitary effluent, cooling tower blowdown waters. For the past two years, pilot operations be been located at the sanitary waste treatment plant using these effluent waters as feed. 
The reverse osmosis pilot. plant had three goals, and they were: (1) to evaluate and recommend the necessary pretreatment equipment required in a reverse osmosis recycling plant; (2) obtain a product water containing less than 100 milligrams per litre of total dissolved solids; and (3) to keep the volume of brine to less than 10,000 gallons per day at a maximum feed volume of 450,000 gallons per day. The need for a product water containing 100 milligrams per litre or less of total dissolved solids was a standard set by our Utilities Department. The goal to keep the volume of brine at less than 10,000 gallons per day was to keep the loading on the new process waste treatment evaporator to a minimum.

It was evident that if we were to accomplish the third goal a brine concentrator of some sort would be required. For this, we have settled on a secondary reverse osmosis unit.

The layout of the primary reverse osmosis pilot plant is shown in Figure 3. The influent which is approximately 20 gallons per minute passes through the pretreatment equipment. This pretreatment can include sand filtration, a 5 micron high pressure bag filter, water conditioning, 


\section{FIGURE 3}

REVERSE OSMOSIS PILOT PLANT,

(PRIMARY UNIT)

\section{INTAKE}

20.0GFM

BRINE

2.2 GPM

(TO SECONDARY UNIT)

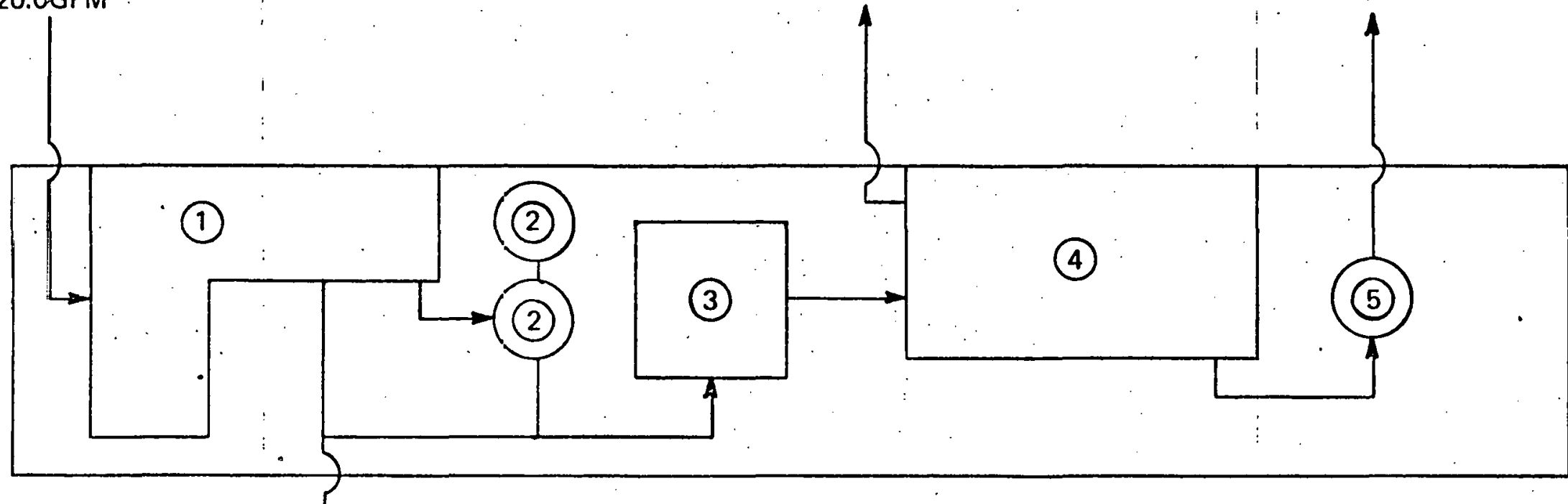

1. PRETREATMENT

2. FEED WATER TANKS

3. CHEMICAL TREATMENT AND

FINAL FILTRATION

4. REVERSE OSMOSIS UNIT - 25,200 GPD

5. PRODUCT WATER TANK 
carbon filtration, a diatomaceous earth filter, and a preheater. Any one piece of the pretreatment equipment, or all of the pretreatment equipment, can be bypassed, if desired, except for the sand filter. The pretreated influent is discharged into the feed tanks and is then pumped through the chemical treatment area. The chemical treatment can include pH control, calcium control using hexametaphosphate, chlorine addition, or chlorine destruction. The influent passes through a final filter which is a one micron CUNO type filter, and then enters the reverse osmosis unit. At the present time, we are operating with cellulose triacetate hollow fiber membranes and are producing approximately $17.5 "$ gallons per minute of product water and 2.2 gallons per minute of brine. This is a water recovery of 89 percent.

Figure 4 shows the layout of the secondary. unit. The brine solution from the primary unit is discharged into a surge tank and is pumped from there into the secondary feed tanks. The secondary feed is pumped from the feed tanks through a chemical treatment area which includes the addition of chlorine and a solution of "dispersant." The treated feed passes through a 25 micron filter into a spiral wound cellulose acetate reverse osmosis unit. We arc producing 2.4 gallnns per minute of secondary 
REVERSE OSMOSIS PILOT PLANT

(SECONDARY UNIT)

SECONDARY FEED

(FRIMARY BRINE!

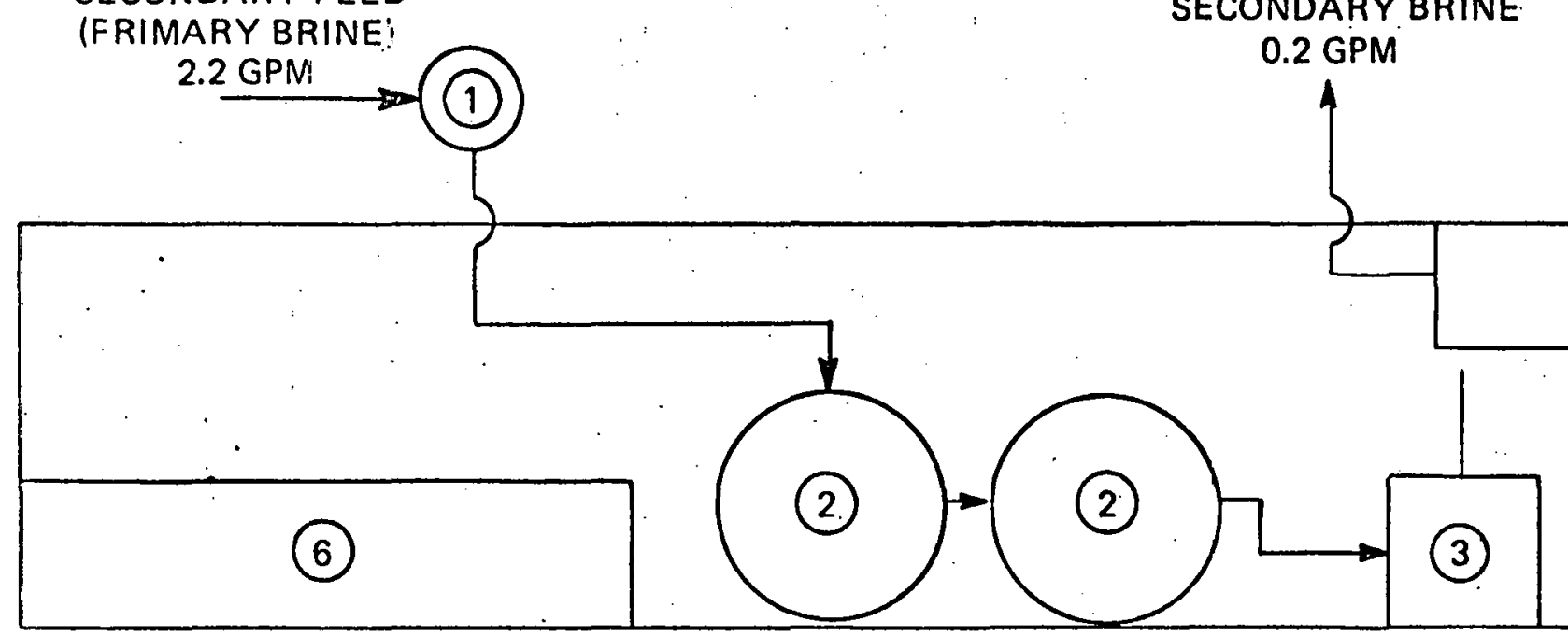

1: SURGE.TANK

-2. SECONDARY FEED WATER TANKS

3. CHEMICAL ADDITIONS AND FINAL FILTRATION

4. SECONDARY REVERSE OSMOSIS UNIT - 3750 GPD

5. SECONDARY PRODUCT WATER TANK

6. PROGRAMMABLE LOGIC CONTROLLER AND PROGRAMMABLE CALCULATOR

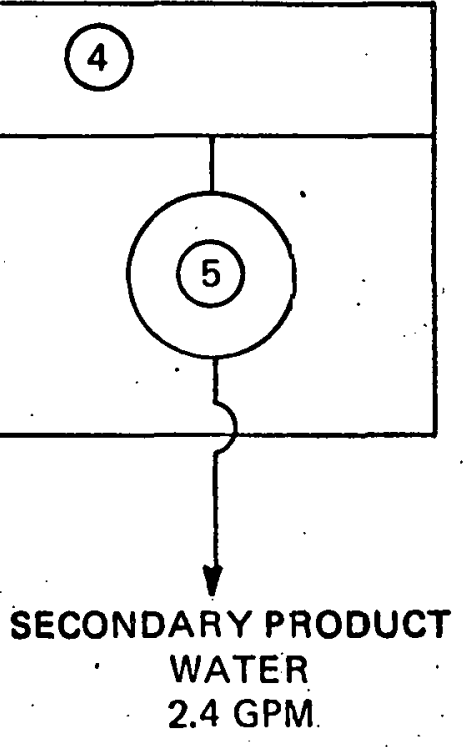


product water and 0.2 gallons per minute of secondary brine. This is a water recovery of 92 percent which produces an overall water recovery of $98+$ percent.

The operation is under the control of a programmable logic controller, using liquid level probes, timers, temperature controls; and chlorine controls. Some of the pilot plant valving is also under the control of the PLC. We have been attempting to use a programmable calculator for data acquisition and as a back-up system for the controller. To date, this has not been successful.

In addition to evaluating the cellulose triacetate membranes, polyamide hollow fiber membranes have also been evaluated in the primary reverse osmosis unit. Table II shows the advantages of the cellulose triacetate membranes over the polyamide membranes.

Lower operating pressures - The operating pressures of the reverse osmosis system have been 110 to 120 pounds less using the cellulose triacetate membranes than polyamide membranes at the same water recoveries.

Higher rejection rates - The rejection rates of the cellulose triacetate membranes have averaged better than 96 porcent; whereas, the rejection rates of the polyamide 


\section{TABLE II}

Advantages of Cellulose Triacetate Membranes over Polyamide Membranes

1. Lower operating pressures

2. Higher rejection rates

3. Higher quality of product water

4. Higher water recoveries

5. Lower inorganic scaling

6. No bacterial fouling 
membranes averaged about 92 percent. The rejection rates were obtained at the same water recoveries.

Higher quality of product water - The quality of the product water from the cellulose triacetate permeators was consistently better than from the polyamide permeators. The quality of product water when using polyamide membranes ranged from 25 to 35 milligrams per litre of total dissolved solids at water recoveries of less than 80 percent and between 30 and 40 milligrams per litre of total dissolved solids at water recoveries greater than 80 percent. When using the cellulose triacetate membranes, the quality of the product water was 20 to 30 milligrams per litre of total dissolved solids for water recoveries of 85 to 90 percent and 15 to 25 milligrams per litre for water recoveries ranging from 80 to 85 percent.

High water recoveries - We have been able to obtain water recoveries of 89 to 90 percent without using high operating pressures. The operating pressures have been maintained at about 245 pounds. The best water recoveries using the polyamide membranes at reasonable pressures--300 to 310 pounds--was 83 to 84 percent.

Lower inorganic scaling - During our operations at the sanitary waste treatment plant, there, have been upsets 
caused by various conditions. When there was an upset, the pilot operations took the full brunt of the upset. When operating with the polyamide membranes, an upset would normally mean that we had to close down the pilot operations and go through a complete cleaning: Very often, we would have to go through one or more of the individual cleanings two or three times. However, we have not had to close down the pilot operations because of an upset at the sanitary treatment plant since changing to the cellulose triacetate membranes. We have done one minor cleaning of the cellulose triacetate membranes since installing them early last May.

No bacterial fouling - The polyamide membranes will be destroyed if they come into contact with chlorine. There- . fore, when we were using the polyamide membranes, the feed water was obtained before the effluent was chlorinated. This resulted in the fouling of the membranes with bacteria. The membranes had to be cleaned about every. 48 to 72 hours of operation to remove the buildup of bacteria. This was done by adding about 12 ounces of BIZ to our feed water tank. We have had no problems with bacteria fouling since switching to the cellulose triacetate membranes because their recommended tolerance for chlorine is one milligram per litre of free chlorine. We have been 
operating using the chlorinated effluent from the. sanitary waste treatment plant, and this contains free chlorine in the range of 0.2 to 0.5 milligrams per litre. An additional advantage is that the flux of the cellulose triacetate membranes is three times greater than the flux of the polyamide membranes.

Table III shows the advantages that polyamide membranes have over the cellulose triacetate membranes.

Less effect by temperature change. - Much better temperature control must be exercised when using cellulose triacetate membranes than when using polyamide membranes if there is to be any control of the product water flow. A.slight temperature change--a degree or two C--would cause a change in the product flow when using cellulose acetate membranes.

Silica can be removed - To remove silica scaling from the surface of the membranes, a solution of sodium hydroxide at a $\mathrm{pH}$ of 11 must be used. The polyamide membranes can withstand a solution at this high $\mathrm{pH}$, but the cellulose triacetate membranes cannot. It is, therefore, essential that there is no colloidal silica in the feed water, and that the concentration of the dissolved s111ca is low. 
$-21-$

\section{TABLE III}

Advantages of Polyamide Membranes over Cellulose Triacetate Membranes

1. Less effect by temperature change

2. Silica scaling can be removed 
Tables IV through VIII show some of the results obtained from the reverse osmosis pilot plant operations. These data have been collected during the past 12 months of operation.

The analyses of our primary product water for fecal coliform, total coliform, and total bacteria have all been negative.

Finally, the reverse osmosis recycling plant. The pretreatment in the recycling plant will include sand filtration, water conditioning, a diatomaceous earth filter, preheating, pH adjustments, and chlorine additions.

Sand filters - These will be used to remove the larger suspended material that may be blown or thrown into the feed pond.

The water conditioning will be used to remove the calcium that naturally occurs in our waters. The calcium concentration range is between 20 and 30 milligrams per litre. There is also a sufficiently high concentration of sulfate in our waste water that without the removal of the calcium, gypsum would precipitate before we obtained our desired 50-fold concentration of the total dissolved solids. 


\section{TABLE IV}

Concentration of Impurities

in Feed for the Primary Reverse Osmosis Unit

\begin{tabular}{|c|c|c|}
\hline & $\begin{array}{c}\text { Range, } \\
\mathrm{mg} / 1\end{array}$ & $\begin{array}{c}\text { Average, } \\
\mathrm{mg} / 1\end{array}$ \\
\hline $\begin{array}{l}\text { Aluminum } \\
\text { Bicarbonate } \\
\text { Calcium } \\
\text { Chloride } \\
\text { Chromium, total }\end{array}$ & $\begin{array}{l}<0.5 \\
6-65 \\
0.1-0.6 \\
30-130 \\
<0.1\end{array}$ & $\begin{array}{l}<0.5 \\
33 \\
0.4 \\
70 \\
<0.1\end{array}$ \\
\hline $\begin{array}{l}\text { Copper } \\
\text { Fluoride } \\
\text { Iron, total } \\
\text { Magnesium } \\
\text { Manganese }\end{array}$ & $\begin{array}{l}<0.1 \\
0.3-0.5 \\
0.1-0.2 \\
0.1-0.7 \\
<0.1\end{array}$ & $\begin{array}{r}<0.1 \\
0.4 \\
0.1 \\
0.3 \\
<0.1\end{array}$ \\
\hline $\begin{array}{l}\text { Nickel } \\
\text { Nitrate } \\
\text { Phosphate } \\
\text { Potassium } \\
\text { Silicon, as Si }\end{array}$ & $\begin{array}{l}<0.1 \\
25-40 \\
0.8-3.0 \\
2-42 \\
5-10\end{array}$ & $\begin{array}{c}<0.1 \\
32 \\
2.0 \\
12 \\
6\end{array}$ \\
\hline $\begin{array}{l}\text { Sodium } \\
\text { Sulfate } \\
\text { Zinc } \\
\text { Total Dissolved Solids } \\
\text { Turbidity, as JTu } \\
\text { pH }\end{array}$ & $\begin{array}{c}104-200 \\
131-349 \\
0: 1-0.3 \\
340-630 \\
0.18-0.57 \\
3.5-6.0\end{array}$ & $\begin{array}{l}155 \\
224 \\
0.2 \\
475 \\
0.31\end{array}$ \\
\hline
\end{tabular}


in Product Water from the Primary Reverse Osmosis Unit

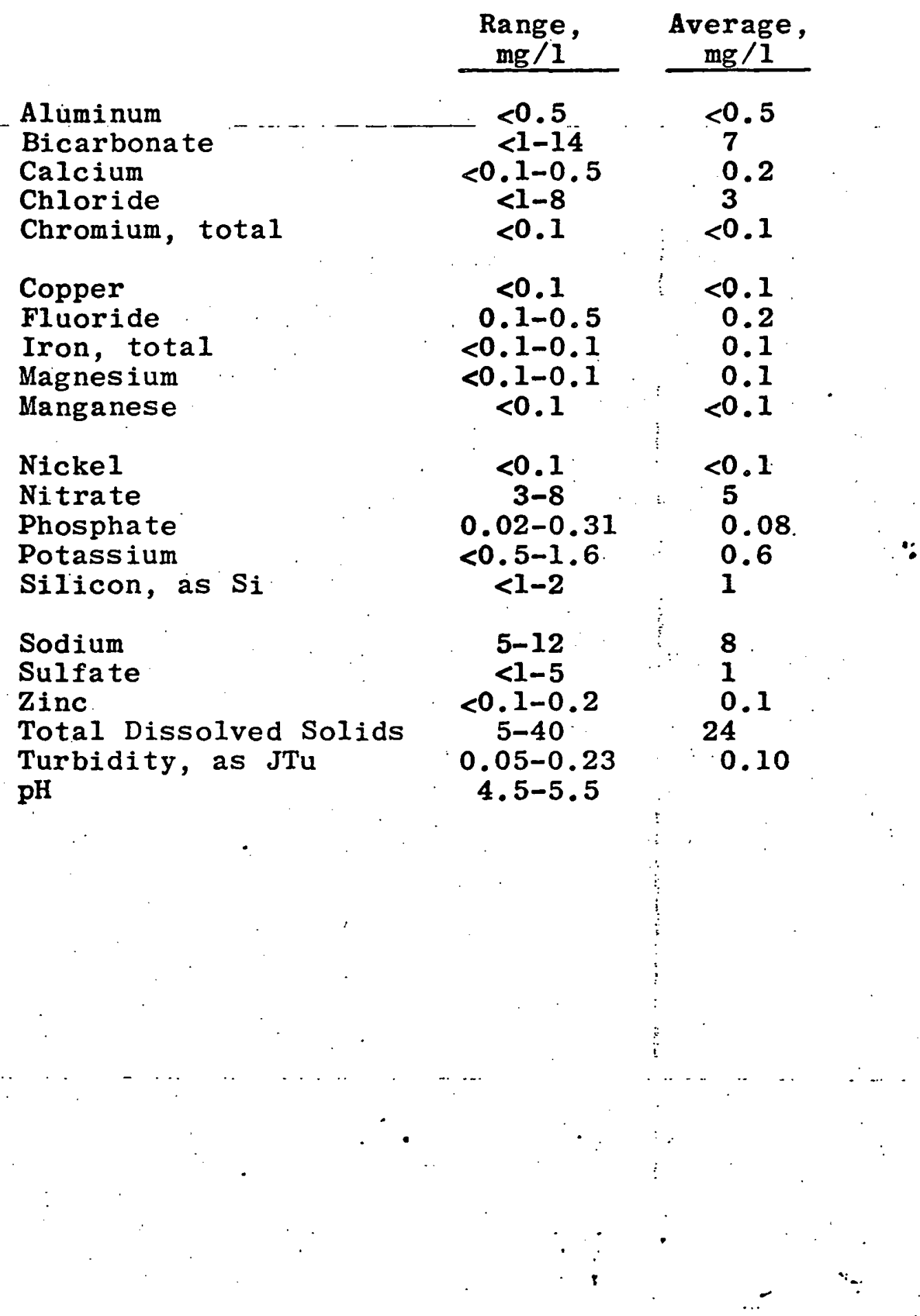




\section{TABLE VI}

Concentration of Impurities

in Brine from the Primary Reverse Osmosis Unit

(Feed for the Secondary Reverse Osmosis Unit)

\begin{tabular}{|c|c|c|}
\hline - & $\begin{array}{c}\text { Range, } \\
\mathrm{mg} / 1\end{array}$ & $\begin{array}{c}\text { Average, } \\
\text { mg/1 }\end{array}$ \\
\hline $\begin{array}{l}\text { Aluminum } \\
\text { Bicarbonate } \\
\text { Calcium } \\
\text { Chloride } \\
\text { Chromium, total }\end{array}$ & $\begin{array}{c}<0.5-1.7 \\
1-40 \\
0.3-1.6 \\
380-640 \\
<0.1-0.1\end{array}$ & $\begin{array}{c}0.8 \\
27 \\
0.7 \\
505 \\
0.1\end{array}$ \\
\hline $\begin{array}{l}\text { Copper } \\
\text { Fluoride } \\
\text { Iron, total } \\
\text { Magnes ium } \\
\text { Manganese }\end{array}$ & $\begin{array}{c}<0.1-0.7 \\
0.3-1.4 \\
0.3-1.0 \\
0.2-0.4 \\
<0.1\end{array}$ & $\begin{array}{r}0.4 \\
1.0 \\
0.6 \\
0.3 \\
<0.1\end{array}$ \\
\hline $\begin{array}{l}\text { Nickel } \\
\text { Nitrate } \\
\text { Phosphate } \\
\text { Potassium } \\
\text { Silicon, as Si }\end{array}$ & $\begin{array}{c}<0.1 \\
150-270 \\
4-37 \\
20-41 \\
40-52\end{array}$ & $\begin{array}{l}<0.1 \\
210 \\
13 \\
27 \\
44\end{array}$ \\
\hline $\begin{array}{l}\text { Sodium } \\
\text { Sulfate } \\
\text { Zinc } \\
\text { Total Dissolved Solids } \\
\text { Turbidity, as JTu } \\
\text { pH }\end{array}$ & $\begin{array}{c}750-1100 \\
1040-1720 \\
0.5-0.8 \\
3520-4590 \\
0.48-1.20 \\
3.0-6.0\end{array}$ & $\begin{array}{c}900 \\
1410 \\
0.6 \\
3920 \\
0.78\end{array}$ \\
\hline
\end{tabular}




\section{TABLE VII}

Concentration of Impurities

in Product Water

from the Secondary Reverse Osmosis Unit

\begin{tabular}{|c|c|c|c|}
\hline & & $\begin{array}{c}\text { Range, } \\
\mathrm{mg} / \mathrm{l}\end{array}$ & $\begin{array}{c}\text { Average, } \\
\mathrm{mg} / 1\end{array}$ \\
\hline $\begin{array}{l}\text { Aluminum } \\
\text { Bicarbonate } \\
\text { Calcium } \\
\text { Chloride } \\
\text { Chromium, total }\end{array}$ & & $\begin{array}{c}<0.5 \\
4-47 \\
<0.1-0.9 \\
200-415 \\
<0.1\end{array}$ & $\begin{array}{c}<0.5 \\
20 \\
0.5 \\
290 \\
<0.1\end{array}$ \\
\hline $\begin{array}{l}\text { Copper } \\
\text { Fluoride } \\
\text { Iron, total } \\
\text { Magnesium } \\
\text { Manganese } \\
\text { Nickel } \\
\text { Nitrate }\end{array}$ & & $\begin{array}{c}<0.1 \\
0.2-0.6 \\
0.1-0.3 \\
<0.1-0.3 \\
<0.1 \\
<0.1 \\
10-75\end{array}$ & $\begin{array}{l}<0.1 \\
0.4 \\
0.2 \\
0.2 \\
<0.1 \\
<0.1 \\
42\end{array}$ \\
\hline $\begin{array}{l}\text { Phosphate } \\
\text { Potassium } \\
\text { Silicon, as Si } \\
\text { Sodium } \\
\text { Sulfate }\end{array}$ & . & $\begin{array}{c}0.2-1.0 \\
8-12 \\
12-24 \\
210-300 \\
20-100\end{array}$ & $\begin{array}{c}0.6 \\
11 \\
17 \\
250 \\
56\end{array}$ \\
\hline $\begin{array}{l}\text { Zinc } \\
\text { Total Dissolved } \\
\text { Turbidity, as JT } \\
\text { pH }\end{array}$ & $\begin{array}{l}\text { Solids } \\
\mathbf{u}\end{array}$ & $\begin{array}{c}<0.1-0.6 \\
510-720 \\
0.10-0.20 \\
4.5-5.5\end{array}$ & $\begin{array}{l}0.3 \\
650 \\
0.15\end{array}$ \\
\hline
\end{tabular}




\section{TABLE VIII}

Concentration of Impurities

in Brine

from the Secondary Reverse Osmosis Unit

$\begin{array}{lcc}\text { Aluminum } & 0.7-2.0 & 1.4 \\ \text { Bicarbonate } & 160-1100 & 580 \\ \text { Calcium } & 3-48 & 32 \\ \text { Chloride } & 1400-2900 & 1990 \\ \text { Chromium, total } & <0.1-0.1 & 0.1 \\ & & \\ \text { Copper } & 0.1-5.7 & 2.5 \\ \text { Fluoride } & 0.8-8.8 & 3.8 \\ \text { Iron, total } & 2.0-8.4 & 4.4 \\ \text { Magnesium } & 4-12 & 8 \\ \text { Manganese } & <0.1-0.1 & 0.1 \\ \text { Nickel } & 0.2-0.6 & 0.4 \\ \text { Nitrate. } & 100-430 & 240 \\ \text { Phosphate } & 41-180 & 97 \\ \text { Potassium } & 160-220 & 190 \\ \text { Silicon, as Si } & 90-210 & 160 \\ & & \\ \text { Sodium } & 4600-6800 & 5400 \\ \text { Sulfate } & 6600-9700 & \mathbf{8 7 4 0} \\ \text { Zinc } & 9-32 & 15 \\ \text { Total Dissolved Solids } 16,900-23,000 & 19,700 \\ \text { Turbidity, as JTu } & 1.1-4.0 & 2.8 \\ \text { pH } & \mathbf{3 . 0 - 6 . 0} & \end{array}$


The diatomaceous earth filters will remove any silt-or colloidal material that may be blown into the feed pond. The D.E. filter should be capable of removing any particle larger than 0.5 micron.

The preheater-will bring the temperature of the feed water to $25^{\circ} \mathrm{C}$ which is the recommended operating temperature. A lowering of the temperature by $1^{\circ} \mathrm{C}$ will reduce the volume of product water by about 3 percent.

The $\mathrm{pH}$ of the present feed water normally is in the range of 6.5 to 7.0 . Our studies have shown that a better operating $\mathrm{pH}$ range would be 4.5 to 5.5 . If we operate at a $\mathrm{pH}$ of 6.0 or above, the volume of the product water produced will be reduced, a loss of flux. This is apparently due to carbonates in the feed water scaling the membranes, and by reducing the $\mathrm{pH}$ we destroy the carbonates before they can cause any scaling.

The chlorine addition is to prevent any bacterial growth which could destroy the reverse osmosis membranes.

Cellulose triacetate hollow fiber membranes will be used in the primary reverse osmosis unit, and cellulose acetate spiral wound membranes will be used in the secondary reverse osmosis unit with a 90 percent water recovery from the primary unit and from the secondary unlt. 
$-29-$

With this type of plant, our pilot plant studies have shown that we can obtain a product water which will contain less than 100 milligrams per litre of total dissolved solids and that the flow of brine to the process waste treatment evaporator will be no greater than 2 percent of the feed stream going to the reverse osmosis" recycling plant. The reverse osmosis recycling plant will be controlled by a programmable logic controller.

This reverse osmosis plant is presently in the design stages. 